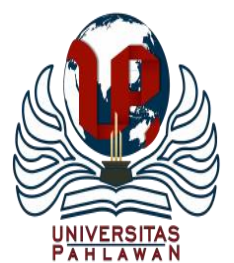

Edukatif : Jurnal Ilmu Pendidikan Volume 3 Nomor 4 Tahun 2021 Halm 2220 - 2236

EDUKATIF: JURNAL ILMU PENDIDIKAN

Research \& Learning in Education

https://edukatif.org/index.php/edukatif/index

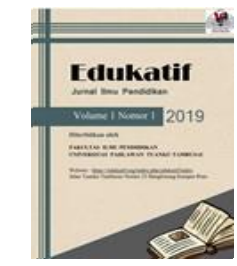

\title{
Pengembangan E-Modul Berbasis STEM untuk Meningkatan Kemandirian Belajar dalam Pembelajaran Jarak Jauh pada Mata Pelajaran Ekonomi
}

\author{
Pingki Jeita Mulyasari ${ }^{1 \otimes}$, Ni’matush Sholikhah ${ }^{2}$ \\ Universitas Negeri Surabaya, Indonesia ${ }^{1,2}$ \\ E-mail : pingki.17080554011@mhs.unesa.ac.id ${ }^{1}$, nimatushsholikhah@unesa.ac.id $^{2}$
}

\begin{abstract}
Abstrak
Permasalahan yang muncul ketika peneliti melakukan observasi di SMA Negeri 14 Surabaya, ditemukan bahwa belum adanya sumber belajar lain yang digunakan dalam pembelajaran jarak jauh selain penggunaan LKPD. Tujuan penelitian ini (1) mendeskripsikan tahapan pengembangan E-Modul berbasis STEM, (2) mendeskripsikan respon peserta didik terhadap E-Modul berbasis STEM, (3) mendeskripsikan efektivitas EModul berbasis STEM, dan (4) mendeskripsikan pengaruh E-Modul berbasis STEM terhadap peningkatan kemandirian belajar pada pembelajaran jarak jauh. Penelitian ini merupakan penelitian pengembangan R\&D dan penelitian eksperimen. Sampel yang digunakan yaitu peserta didik kelas XI IPS SMA Negeri 14 Surabaya yang terdiri dari 34 peserta didik. Berdasarkan hasil validasi para ahli E-Modul berbasis STEM yang dikembangkan dalam kategori layak, respon peserta didik terhadap kepraktisan E-Modul berbasis STEM dalam kategori layak, berdasarkan uji gain score terdapat peningkatan kemandirian, dan berdasarkan hasil paired samples test terdapat pengaruh penggunaan E-Modul terhadap kemandirian belajar. Dengan demikian dapat disimpulkan bahwa E-Modul berbasis STEM efektif digunakan untuk meningkatkan kemandirian belajar pada pembelajaran jarak jauh pada mata pelajaran ekonomi.
\end{abstract}

Kata Kunci: E-Modul, STEM, Kemandiran belajar.

\begin{abstract}
The problems that arise when researchers conducted observations in SMA Negeri 14 Surabaya, it was found that the absence of other learning resources that are used in distance learning in addition to the use of LKPD there. The purpose of this study (1) describes the stages of development of E-Module based STEM, (2) describe the response of students towards E-Module based STEM, (3) describe the effectiveness of E-Module based, STEM, and (4) describe the effect of E-Module based STEM against self-regulated learning in distance learning. This research is the development of $R \& D$ and experimental research. The sample used is the students of class XI IPS SMA Negeri 14 Surabaya, which consists of 34 students. Based on the results of the validation of the experts of E-Module based STEM developed in the category, the response of students to the practicality of E-Module based STEM category, based on the test gain score there is an increase in selfreliance, and based on the results of paired samples test there is influence of the use of the E-Module of learning independence. It can be concluded that the E-Module based STEM effectively used to improve selfregulated learning in distance learning on economic subjects.
\end{abstract}

Keywords: E-Modules, STEM, learning independence.

Copyright (c) 2021 Pingki Jelita Mulyasari, Ni'matush Sholikhah

$\triangle$ Corresponding author

Email : pingki.17080554011@mhs.unesa.ac.id

DOI : https://doi.org/10.31004/edukatif.v3i4.1158

ISSN 2656-8063 (Media Cetak)

ISSN 2656-8071 (Media Online) 
2221 Pengembangan E-Modul Berbasis STEM untuk Meningkatan Kemandirian Belajar dalam Pembelajaran Jarak Jauh pada Mata Pelajaran Ekonomi - Pingki Jelita Mulyasari, Ni'matush Sholikhah

DOI: https://doi.org/10.31004/edukatif.v3i4.1158

\section{PENDAHULUAN}

Pandemi COVID 19 yang terjadi di Indonesia menyababkan perubahan seluruh aspek kehidupan dalam masyarakat, mulai dari cara kerja, cara beraktifitas, cara bertransaksi dan lain sebagainya. Tak tekecuali pada dunia pendidikan, dengan adanya pandemi tersebut menjadikan aktifitas sekolah terganggu dimana dengan adanya peliburan sekolah dan berganti dengan belajar dari rumah (learning from home). Dalam skala global, menurut UNESCO sejak 12 Maret 2020 untuk pencegahan penyebaran Virus Corona terdapat 29 negara yang mengambil kebijakan untuk memberhentikan seluruh kegiatan belajar di sekolah. Kemudian tanggal 18 Maret 2020 sebanyak 112 negara yang menyusul mengambil keputusan serupa. Dilihat dari data tersebut sebanyak 849,4 juta peserta didik dan mahasiswa terdampak atas pandemi ini (Pancawati, 2020).

Berlandaskan Peraturan Pemerintah No 21 tahun 2020 tentang Pembatasan Sosial Berskala Besar, diambil kebijakan untuk meliburkan sekolah demi memutus rantai penyebaran virus corona. Pembalajaran yang dilakukan pada saat pedemi covid 19 ini dengan pembelajaran jarak jauh (PJJ) atau learning from home. Kebijakan ini mempengaruhi perubahan proses pembelajaran mulai dari kurikulum, metode pembelajaran hingga assesment belajar yang mana harus fleksibel sesuai dengan keadaan saat ini. Sehingga pendemi ini mempengaruhi seluruh tingkatan pendidikan di Indonesia. Dalam kondisi new normal saat ini, guru dapat mengajar peserta didik dengan metode mengajar synchronous atau asynchronous. Metode synchronous adalah dimana guru dan peserta didik bertemu secara online di platform online tertentu untuk mengajar dan berkomunikasi sebuah pelajaran sementara sistem asynchronous memungkinkan guru dan peserta didik untuk berinteraksi pada waktu dan tempat yang berbeda (Amiti, 2020).

Pandemi yang terjadi sejak Maret 2020 belum terprediksi sebelumnya, sehingga memang belum ada persiapan yang matang untuk menghadapinya. Dalam pembelajaran jarak jauh, masih ada persoalan yang perlu diperhatikan salah satunya media pembajaran karena ini akan berakibat pada pemaparan materi kurang mudah dicerna (Suwasono, 2013). Seperti pembelajaran jarak jauh yang selama ini dilakukan masih dikatakan belum efektif. Sesuai dengan pernyataan dari Retno seorang Komisioner KPAI, dalam rapat Komisi X DPR yang dilakukan pada bulan Juni mengatakan bahwa pembelajaran jarak jauh saat ini adanya hubungan antara guru dengan peserta didik masih dikatakan kurang. Pembelajaran yang disiasati dengan pemberian tugas yang memanfaatan grup aplikasi WhatsApp, dikatakan masih menjadi beban untuk peserta didik (Astuti \& Prabowo, 2020). Kemandirian belajar dari peserta didik dalam pembelajaran jarak jauh merupakan hal yang utama dalam proses pembelajaran (Prawiyogi et al., 2020). Belajar mandiri ini diperlukan peserta didik saat mencari dan menemukan selama proses pembelajaran dan secara mandiri menarik kesimpulan yang telah dipelajarinya.

Setiap peserta didik harus memliki Self-Regulate Learning dimana peserta didik dapat mandiri dalam menyelesaikan tugas dan mampu mengatasi suatu masalah dalam hal belajar. Ketika belajar dari rumah peserta didik diharapkan memiliki tingkat mandiri, tanggung jawab dan self regulated learning yang lebih tinggi. Sebab itu perlu bahan ajar yang terdapat materi sehingga bisa digunakan peserta didik untuk belajar mandiri dalam pembelajaran jarak jauh saat ini, yang mana dapat diberikan modul sehingga peserta didik dapat belajar dengan mudah. Bahan ajar merupakan sumber belajar yang sistematis yang memuat kemampuan-kemampuan yang harus dimiliki peserta didik dan digunakan sepanjang proses pembelajaran untuk mencapai tujuan pembelajaran. Namun pada kenyataannya, penggunaan bahan ajar berupa modul cetak yang hanya berisi teks dan gambar belum memenuhi tuntutan pembelajaran. Menurut Vembriarto (dalam Fausih \& Danang, 2015) salah satu media bahan ajar yang efisien dan mengutamakan kemandirian peserta didik adalah E-modul. E-Modul yang disajikan dengan format elektronik ini tidak terikat oleh waktu dan tempat serta memberikan kemudahan bagi peserta didik untuk mempelajari ketika pembelajaran jarak jauh. Dimana E-Modul dirancang untuk pengguna dapat belajar secara mandiri dengan dilengkapi petunjuk didalamnya kemudian dapat tertarik dalam proses belajar sebab dapat diaskes dengan mudah. Selain itu guru 
dapat dengan mudah melaksanan pembelajaran walaupun berbeda tempat dengan peserta didik. Dengan penggunaan E-Modul peserta didik memiliki sumber belajar dalam pembelajaran jarak jauh dengan diimplementasikan secara mandiri di rumah. E-Modul yang digunakan sebagai bahan ajar harus memuat pendekatan dan prinsip yang jelas.

Salah satu pendekatan yang memenuhi standar pendidikan abad 21 yaitu pendekatan Sciene, Technology, Engineering, and Mathematics (STEM). Pendekatan ini merupakan hasil inovasi yang bertujuan memberdayakan peserta didik untuk membenamkan diri dalam dunia kerja abad 21 yang menuntut manusia memiliki kemampuan dan keterampilan untuk memecahkan masalah yang tidak terlepas dari pemanfaatan teknologi dan inovasi (Anggraini \& Siti, 2017). Kegiatan pembelajaran dengan penerapkan STEM tediri dari 4C yaitu creativity, critical thingking, collaboration, dan communication. Penerapan pendekatan STEM ini dimaksudkan agar peserta didik memiliki empat aspek yang berkaitan pada suatu pokok bahasan untuk membantu peserta didik memecahkan masalah dan menarik kesimpulan. Pembelajaran STEM merupakan kolaborasi dari keempat bidang ilmu yang serasi antar masalah yang terjadi di dunia nyata (Torlakson, 2014). Sesuai dengan penelitian sebelumnya yang dilakukan oleh (Suryani et al., 2020) mengatakan bahwa modul digital berbasis STEM mampu menarik motivasi siswa dan meningkatkan kemampuan peserta didik untuk belajar secara mandiri. Namun pada penelitian tersebut, sebatas menguji kepraktisan penggunaan modul digitas, sedangkan pada penelitian ini melihat pengaruh dan efektivitas dari E-modul terhadap kemandirian belajar.

Berdasarkan studi pendahuluan di SMA Negeri 14 Surabaya dengan guru dan peserta didik ekonomi kelas XI, dimana untuk pembelajaran daring peserta didik diberikan materi melalui grup aplikasi WhatsApp dengan pemberian materi dalam bentuk Word. Setelah memberikan materi, guru memberi tugas di lembar kerja peserta didik cetak. Dari wawancara dari guru menyatakan bahwa belum ada modul belajar selain LKPD yang ada. Selain itu guru mengungkapkan bahwa peserta didik memiliki stimulus atau dorongan belajar yang berbeda pada tingkatannya serta banyak peserta didik yang bergantung dengan sumber belajar yang berasal dari guru, sehingga menunjukkan kemandirian belajar peserta didik masih rendah terutama terkait dengan referensi sumber belajar.

Materi di kelas XI IPS semester dua terdapat salah satu kompetensi dasar yaitu materi Perdagangan Internasional, dibagi menjadi konsep perdagangan internasional dan kebijakan perdagangan internasional. Materi Perdagangan Internasional memiliki karakteristik dengan istilah-istilah ekonomi yang tidak mudah untuk dipahami peserta didik yang mana materi ini bersifat teoritis. Secara teoritis materi ini membahas tentang perdagangan internasional yang secara umum adanya pengetahuan yang dekat sekali dengan kehidupan peserta didik. Pada kenyataannya dengan metode pembelajaran konvensional, terutama dengan istilah ekonomi yang banyak digunakan dalam subtansi perdagangan internasional peserta masih kesulitan untuk memahami perdagangan internasional terlebih dengan adanya pandemic ini akan menjadikan regulasi perdagangan internasional berbeda dengan sebelumnya.

Dari uraian diatas peneliti melakukan penelitian pengembangan bahan ajar berupa E-modul berbasis STEM pada materi Perdagangan Internasional, penelitian pengembangan ini bertujuan untuk mendiskripsikan pengembangan E-modul, respon peserta didik, efektivitas E-modul, dan pengaruh E-modul terhadap kemandirian belajar. Diharapkan penelitian ini dapat meningkatkan kemandirian belajar peserta didik sehingga dapat berpengaruh positif terhadap pemahaman serta hasil belajar siswa pada materi perdagangan internasional.

\section{METODE PENELITIAN}

Penelitian ini adalah penelitian pengembangan dan penelitian eksperimen menggunakan analisis data kuantitatif. Metode penelitian dan pengembangan (R\&D) adalah metode penelitian untuk pembuatan produk 
tertentu. Menurut Brog dan Gall (Ariana et al., 2020) penelitian pengembangan adalah metode penelitian yang digunakan untuk mengembangkan atau memvalidasi produk-produk yang bermanfaat bagi pendidikan dan pembelajaran. Tujuan sebenarnya dari pengembangan dan penelitian adalah untuk menghasilkan produk melalui proses pengujian atau verifikasi agar tercipta produk yang efektif, praktis, dan bermanfaat bagi pendidikan dan pelatihan. Produk yang dikembangkan dapat berupa perangkat lunak atau software. Penelitian dilakukan melalui pengembangan berupa e-modul dengan materi Perdagangan Internasional. Metode penelitian eksperimen menurut (Sugiyono, 2015) merupakan metode penelitian yang digunakan untuk mencari pengaruh tertentu terhadap yang lain dalam kondisi terkendali atau dapat diartikan sebagai penelitian dengan melakukan percobaan pada kelompok eksperimen. Untuk mengukur pengaruh E-Modul berbasis STEM terhadap kemandirian peserta didik pada pembelajaran jarak jauh mata pelajaran ekonomi dengan menanfaatkan metode penelitian eksperimen.

Prosedur penelitian dengan menggunakan model pengembangan 4-D yang dikembangkan oleh Thiagaraja, Semmel, dan Semmel, terdapat empat tahap yaitu define (pendefinisian), design (perancangan), develop (pengembangan), dan disseminate (penyebaran). Namun dalam penelitian ini tidak sampai tahap penyebaran, akan tetapi hanya sampai tahap develop. Data yang telah diperoleh selama pengembangan emodul, kemudian akan dianalisis oleh peneliti dengan tahapan analisis kualitatif dan kuantitatif. Analisis kualitatif ini diperoleh dari pengumpulan data dari observasi, wawancara, dan angket. Data tersebut kemudian dianalisis secara deskriptif dan beberapa saran dari para ahli digunakan untuk lebih menyempurnakan produk. Sedangkan analisis kuantitatif adalah data yang bersifat numerik (angka) dan mempunyai arti yang tidak menggambarkan apa adanya sebelum dilakukan pengolahan data. Analisis kuantitatif dimaksudkan untuk menggambarkan kualitas bahan ajar yang dikembangkan berdasarkan penilaian dari validator ahli, meliputi: ahli materi, ahli media, dan evaluasi.

a) Validasi Ahli

Teknik analisis data validasi ahli materi, ahli media dan ahli evaluasi menggunakan rumus:

$$
\rho=\frac{\Sigma x}{\Sigma x i} \times 100 \%
$$

$$
\begin{aligned}
& \text { Keterangan: } \\
& \rho=\text { Presentasi } \\
& \Sigma x=\text { Jumlah nilai keseluruhan jawaban } \\
& \Sigma x i=\text { Jumlah keseluruhan nilai ideal dalam item } \\
& \text { Sumber : (Arikunto, 2012) }
\end{aligned}
$$

Dari hasil yang tampak, data yang semula berupa kuantifikasi persentase diubah menjadi data kualitatif deskriptif. Kualitas kelayakan produk E-Modul dapat ditentukan dengan kriteria kelayakan hasil validasi sebagai berikut:

Tabel 1. Tabel kriteria kelayakan hasil penilaian ahli

\begin{tabular}{lll}
\hline $\begin{array}{c}\text { Tingkat } \\
\text { Pencapaian }\end{array}$ & Kualifikasi & \multicolumn{1}{c}{ Keterangan } \\
\hline $\mathbf{8 1 \% - 1 0 0 \%}$ & Sangat layak & Tidak perlu direvisi \\
\hline $\mathbf{6 1 \% - 8 0 \%}$ & Layak & Tidak perlu direvisi \\
\hline $\mathbf{4 1 \% - 7 0 \%}$ & Cukup layak & Direvisi \\
\hline $\mathbf{2 1 \% - 6 0 \%}$ & Kurang layak & Direvisi \\
\hline$<\mathbf{2 0 \%}$ & Tidak layak & Direvisi \\
\hline ber : (Arikunto, 2012) & &
\end{tabular}

b) Angket Peserta didik

Untuk mengetahui respon peserta didik mengenai kelayakan E-modul berbasis STEM, oleh karena itu perlu penyebaran angket. Penelitian ini memakai angket bedasarkan skala likert dengan alternative lima 
jawaban. Hasil penilaian yang dijawab dari angket peserta didik, dapat dianalisis secara deskripitif kuantitaif dengan presentase masing-masing komponen dalam hasil angket. Berikut skor angket respon peserta didik:

Tabel 2. Tabel skor angket peserta didik

\begin{tabular}{ll}
\hline Skala Likert & Penyataan Positif \\
\hline SS (Sangat Setuju) & 5 \\
\hline S (Setuju) & 4 \\
\hline N (Netral) & 3 \\
\hline TS (Tidak Setuju) & 2 \\
\hline STS (Sangat Tidak Setuju & 1 \\
Sumber: (Sugiyono, 2012) &
\end{tabular}

Menggunakan tolok ukur untuk mengubah nilai rata-rata yang diperoleh menjadi data kualitatif atau interval pada skala empat poin menurut Djemari Mardapi (2008), untuk mengetahui nilai kelayakan dari Emodul dari respon peserta didik.

Tabel 3. Tabel rentang skor nilai kelayakan

\begin{tabular}{ccl}
\hline \multicolumn{2}{c}{ Rentang Skor } & \multicolumn{1}{c}{ Keterangan } \\
\hline$X \geq \bar{X}+1 . S B x$ & $X \geq 3$ & Sangat Baik \\
\hline $\bar{X}+1 . S B x>X$ & $3>X$ & Baik \\
$\geq \bar{X}$ & $\geq 2.5$ & \\
\hline $\bar{X}>X \geq \bar{X}+1 . S B x$ & $2.5>X$ & Tidak Baik \\
& $\geq 2$ & \\
\hline$X<\bar{X}+1 . S B x$ & $X<2$ & Sangat Tidak Baik \\
\hline
\end{tabular}

Keterangan:

$\bar{X}=$ Rata-rata skor ideal $=1 / 2($ skor maksimal ideal+skor maksimal ideal $)$

$S B x=$ Simpanan baku ideal $=1 / 6$ (skor maksimal ideal-skor minimal ideal)

$X=$ Skor yang dicapai

c) Karakter Kemandirian

Penyebaran angket dilaksanakan untuk mengetahui peningkatan kemandirian peserta didik. Bagianbagian yang diamati sesuai dengan masing-masing indikator kemandirian. Menurut Song dan Hill (dalam Wal \& Aulia, 2019) terdapat aspek-aspek kemandirian belajar peserta didik yang dapat digunakan untuk indikator mengukur kemandirian belajar, sebagai berikut 1). Personal Attribute merupakan faktor yang menyangkut dalam aspek-aspek kepribadian seseorang. Aspek personal attribute berhubungan dengan motivasi belajar, penggunaan sumber belajar, dan strategi belajar; 2) Process, aspek yang berkaitan dengan otonomi proses pembelajaran yang dilakukan peserta didik mulai dari perencanaan belajar, monitoring belajar, evaluasi pembelajaran, 3) Learing Context, faktor lingkungan serta bagaimana faktor tersebut dapat memperngaruhi tingkat kemandirian belajar peserta didik. Tingkat kemandirian peserta didik dapat dinyatakan meningkat apabila terjadi peningkatan sebelum penggunaan E-Modul dan sesudah digunakannya. Secara klasikal peningkatan kemandirian peserta didik dianalisis mengunakan bantuan SPSS, berikut adalah langkah-langkah pengolahan data pretest dan posttest dalam penelitian ini:

1. Uji Normalitas

Uji normalitas merupakan uji yang dilakukan sebelum atau prasyarat melakukan analisis data. Tujuan dari pengujian ini adalah untuk mengetahui apakah data yang ada berdistribusi normal sehingga dapat digunakan untuk statistik parameter. Penelitian ini memakai uji normalitas Kolmogorov-Smirnov Test, menurut (Ghozali, 2016) dasar keputusan uji normalitas yaitu :

a. Apabila nilai sig diatas 5\% maka data memiliki distribusi normal.

b. Apabila nilai sig dibawah 5\% maka data memiliki tidak distribusi normal. 
2225 Pengembangan E-Modul Berbasis STEM untuk Meningkatan Kemandirian Belajar dalam Pembelajaran Jarak Jauh pada Mata Pelajaran Ekonomi - Pingki Jelita Mulyasari, Ni'matush Sholikhah

DOI: https://doi.org/10.31004/edukatif.v3i4.1158

2. $\quad$ Uji Paired Sample T Test

Uji t sampel berpasangan dapat digunakan untuk menunjukkan apakah sampel berpasangan telah berubah secara signifikan. Bila skala data bersifat kuantitatif (interval atau rasio), maka uji ini digunakan sebagai uji komparatif. Penelitian ini menggunakan data interval, sehingga digunakan uji T. Hasil Uji Paired Sample T Test ditentukan oleh nilai signifikansinya, menurut (Damayanti, E., Nurazizah, E., \& Rahayu, 2010) nilai tersebut kemudian menentukan keputusan yang diambil dalam penelitian :

a. Nilai $\operatorname{sig}(2$-tailed $)<0.05$ menunjukkan adanya perbedaan yang signifikan antara variabel awal dengan variabel akhir.

b. Nilai sig (2-tailed) $>0.05$ menunjukkan adanya tidak terdapat perbedaan yang signifikan antara variabel awal dengan variabel akhir.

\section{Uji Score Gain}

Untuk mengetahui selisih perbedaan peningkayan dapat diketahui melalui rumus Gain ternormalisasi.

$$
g=\frac{\text { Skor Setelah }- \text { Skor Sebelum }}{\text { Skor Maksimum }- \text { Skor Sebelum }}
$$

Tabel 4. Tabel kriteria Skor Gain ternormalisasi

\begin{tabular}{cc}
\hline Skor Gain Ternormalisasi & $\begin{array}{c}\text { Kriteria Gain } \\
\text { Ternormalisasi }\end{array}$ \\
\hline $\mathbf{0 , 7}<\boldsymbol{g}>\mathbf{1}$ & Peningkatan Tinggi \\
\hline $\mathbf{0 , 3} \leq \boldsymbol{g} \geq \mathbf{0 , 7}$ & Peningkatan Sedang \\
\hline $\mathbf{0}<\boldsymbol{g}>\mathbf{0 , 3}$ & Peningkatan Rendah \\
\hline Sumber: $($ Hake, 1999$)$ &
\end{tabular}

\section{HASIL DAN PEMBAHASAN PENELITIAN}

Penelitian pengembangan ini dilakukan di XI IPS 1 SMA Negeri 14 Surabaya menggunakan model penelitian pengembangan, mewujudkan produk berupa E-Modul berbasis STEM dengan materi Perdagangan Internasional. Produk dikemas dalam bentuk flipbook, yang diberikan kepada peserta didik supaya dapat digunakan agar dapat secara mandiri belajar dari rumah. Berikut merupakan penjabaran tahapan proses penelitian pengembangan 4-D yang dikembangkan oleh Thiagaraja, Semmel, dan Semmel mulai dari pendefinisian, perencanaan, dan pengembangan :

A. Define (Tahap Pendefinisian)

1) Front-end analysis

Melakukan analisis ujung depan untuk mengetahui masalah dasar yang dihadapi oleh peserta didik atau guru SMA Negeri 14 Surabaya. Berdasarkan observasi yang dilakukan oleh peneliti pada guru mata pelajaran ekonomi kelas XI dengan wawancara, diketahui dalam kegiatan belajar mengajar selama pandemic covid 19 ini dilakukan secara daring. Ketika pembelajaran dilakukan dengan daring guru ekonomi memberikan materi melalui grup WhatsApp untuk mempelajari materi dari LKPD. Bahan ajar yang digunakan hanya berupa LKPD cetak yang tersedia, jadi dapat dikatakan bahan ajar masih minim. Selain itu kurikulum SMA Negeri 14 Surabaya ini menggunakan kurikulum 2013 dengan integrasi pendekatan STEM. Oleh karena itu peneliti mengembangkan sumber belajar berupa E-Modul berbasis Science, Technology, Engineering and Mathematics (STEM).

\section{2) Learner analysis}

Pada tahap ini, peneliti menganalisis karakteristik dari peserta didik yang merupakan calon pengguna modul. Subjek dari penelitian ini adalah peserta didik kelas XI IPS 1 SMA Negeri 14 Surabaya sebanyak 34 peserta didik. Menurut peserta didik materi yang ada di LKPD belum lengkap, sehingga masih perlu mencari tambahan bahan ajar dari berbagai sumber. Sehingga dibutuhkan bahan ajar tambahan yang dapat diakses 
secara mandiri guna menunjang proses pembelajaran untuk mendorong tingkat pemahaman materi peserta didik. Dengan rentang usia pelajar berada di umur 17-18 tahun, yang mana rentang tersebut merupakan masih dikategorikan dalam usia remaja dengan gaya belajar yang berbeda-beda, maka modul yang akan dikembangkan disusun berisi gambar dan video yang menunjang pembelajaran. Selain itu secara keseluruhan peserta didik dapat dan memiliki smartphone serta pembelajaran saat ini secara daring, oleh karena itu modul disusun secara elektronik.

\section{3) Concept analysis}

Perumusan analisis dilakukan dengan menandai konsep utama yang akan berikan pada peserta didik dan disusun dengan sistematis dengan mengacu pada silabus mata pelajaran ekonomi kelas XI IPS SMA yang diterapakan di SMA Negeri 14 Surabaya. Analisis konsep merupakan hasil analisis dari KD yang dijabarkan dalam bentuk peta konsep.

\section{4) Task analysis}

Analisis tugas dilakukan dengan mencatat pengetahuan utama yang harus dimiliki oleh peserta didik, perumusan melalui cara pemetaan materi-materi berdasarkan analisis konsep. Berdasarkan hasil analisis, Emodul dibagi menjadi beberapa materi utama, sehingga materi yang ditampilkan dalam modul disusun dalam dua kegiatan pembelajaran. Disetiap kegiatan pembelajaran beberapa tugas yang harus dikerjakan peserta didik, berupa penugasan mandiri dengan pencarian literature dan uji kemampuan dengan studi kasus yang harus diselesaikan pada tiap kegiatan pembelajaran. Selain itu juga di akhir kegiatan pembelajaran terdapat soal evaluasi yang harus dikerjakan oleh peserta didik untuk mengetahui tingkat pemahaman materi Perdagangan Internasional.

\section{5) Specifying instructional objectives}

Perumusan tujuan pembelajaran didasarkan pada kompetensi inti (KI) yang tercantum dalam kurikulum, yang terbagi dalam beberapa materi, dan materi tersebut harus disesuaikan dengan tujuan pembelajaran.

\section{B. Design (Tahap Perencanaan)}

Penyusunan pada tahap perencaan dilakukan dengan prototype, sehingga dapat memudahkan peneliti dalam merancang pengembangan E-Modul berbasis STEM yang sesuai dengan panduan pembuatan E-Modul secara menyeluruh. Berikut merupakan langkah-langkah dari tahap perencaan:

1) Menyusun Peta Kompetensi

Penyusunan berdasarkan kompetensi dasar yang akan dimasukkan pada E-Modul. Pada tahap desain ini, memberikan gambaran awal tentang apa yang ditampilkan pada E-modul Perdagangan Internasional. Peta kompetensi dibagi menjadi dua kegiatan pembelajaran yaitu Konsep dan Kebijakan Perdagangan Internasional; serta Alat dan Neraca Pembayaran

2) Penyusunan Materi

Penyajian materi disesuiakan dengan kompetensi dasar (KD) yang ada pada silabus kelas XI.

3) Penetapan Format

Format yang digunakan dalam E-Modul Perdagangan Internasional adalah sebagai berikut:

a. Font yang digunakan adalah Arial, ukuran 11, spasi antar baris 1,15 yang proporsional dengan judul, subbagian, dan isi naskah.

b. Penyusunan materi diorganisasikan secara sistematis dan berurutan.

c. Sampulnya terdiri dari intregrasi gambar, warna, bentuk, dan ukuran font yang menarik.

d. Mempergunakan ukuran A4 untuk kertas dan format kolom .

e. Menggunakan ruang kosong secara proposional.

4) Penulisan Naskah Modul

Penulisan naskah E-Modul sebagai berikut: 
a) Rancangan E-modul meliputi: halaman sampul, halaman penyusun, kata pengantar, daftar isi, glosarium, pendahuluan, keterkaitan pendekatan STEM, peta konsep, kegiatan pembelajaran 1 , kegiatan pembelajaran 2, evaluasi, dan daftar pustaka.

b) Cover E-modul

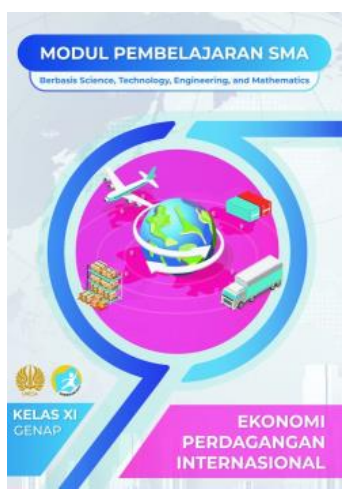

Gambar 1. Cover E-modul

Sampul E-modul terdiri atas judul "Modul Pembelajaran SMA Berbasis Science, Technology,

Engineering and Mathematic: Perdagangan Internasional".

c) Halaman Penyusun

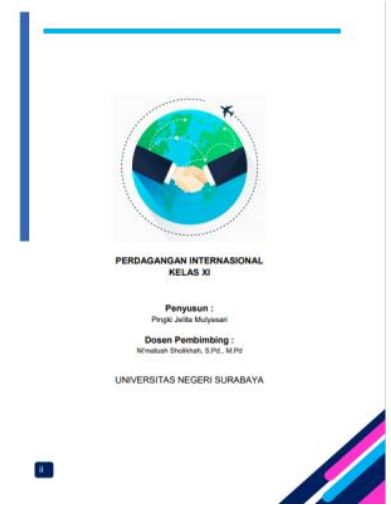

Gambar 2. Halaman Penyusun

Halaman penyusun terdiri atas nama penyusun E-Modul dan dosen pembimbing.

d) Kata Pengantar
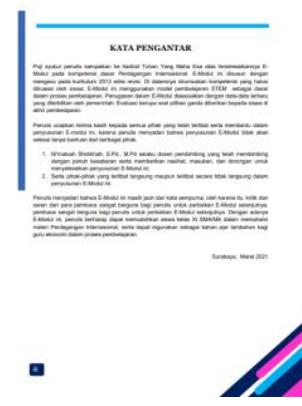

Gambar 3. Kata Pengantar

Kata pengantar memuat beberapa komponen seperti gambaran umum dari E-modul, ucapan syukur penulis, ucapan terima kasih, dan harapan penulis atas pengembangan E-modul.

e) Daftar Isi 

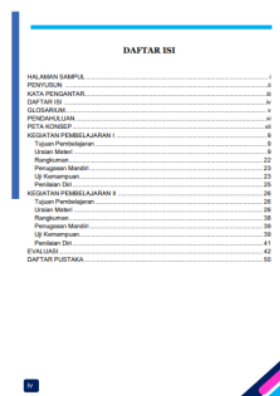

Gambar 4. Daftar Isi

Daftar isi dalam E-Modul bertujuan untuk memudahkan pengguna dalam menemukan sub materi dan berpindah dari kehalaman yang diinginkan.

f) Glosarium

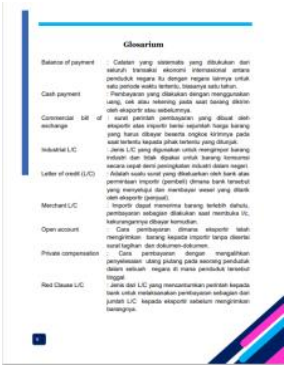

Gambar 5. Glosarium

Glosarium memuat daftar alfabet kata atau istilah yang penting yang dilengkapi dengan penjelasannya (definisi).

g) Pendahuluan

Penduluan terdiri atas deskripsi dari E-modul, Kompetensi Inti, Kompetensi Dasar, Indikator, dan petunjuk penggunaan E-Modul.

h) Peta Konsep

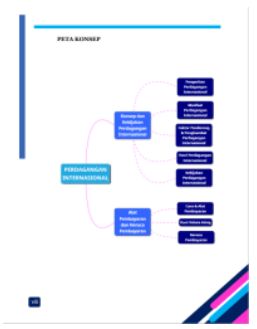

Gambar 6. Peta Konsep

Peta konsep menjabarkan tentang materi yang ada di dalam E-Modul yang mana akan dipelajari oleh pengguna.

i) Kegiatan Pembelajaran

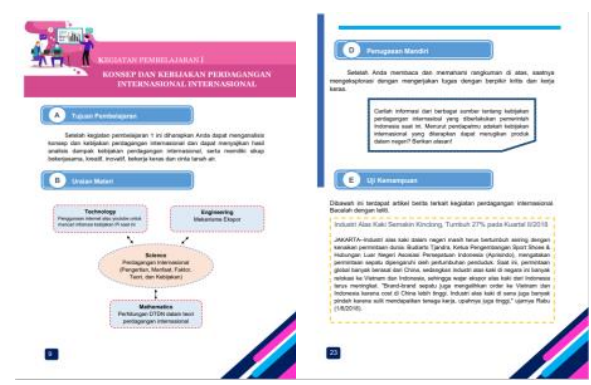

Gambar 7. Kegiatan Pembelajaran 
Kegiatan pembelajaran masing-masing berisi tujuan pembelajaran, uraian materi, rangkuman, penugasan mandiri, uji kemampuan, dan penilaian diri.

j) Evaluasi berisikan soal evaluasi, kunci jawaban, serta ketentuan penilaian.

C. Develop (Tahap Pengembangan)

Tahap berikutnya merupakan tahap pengembangan dengan meliputi hasil penilaian atau validasi ahli dan uji coba pengembangan, pada tahap ini bertujuan menghasilkan produk yang sudah direvisi berdasarkan atas komentar dan saran dari para ahli kemudian direvisi oleh penulis. Berikut merupakan gambaran E-Modul sebelum dan sesudah direvisi dari ahli.

Tabel 5. Tabel hasil sebelum dan sesudah perbaikan

\begin{tabular}{l} 
No. \\
\hline 1.
\end{tabular}


2230 Pengembangan E-Modul Berbasis STEM untuk Meningkatan Kemandirian Belajar dalam Pembelajaran Jarak Jauh pada Mata Pelajaran Ekonomi - Pingki Jelita Mulyasari, Ni'matush Sholikhah

DOI: https://doi.org/10.31004/edukatif.v3i4.1158

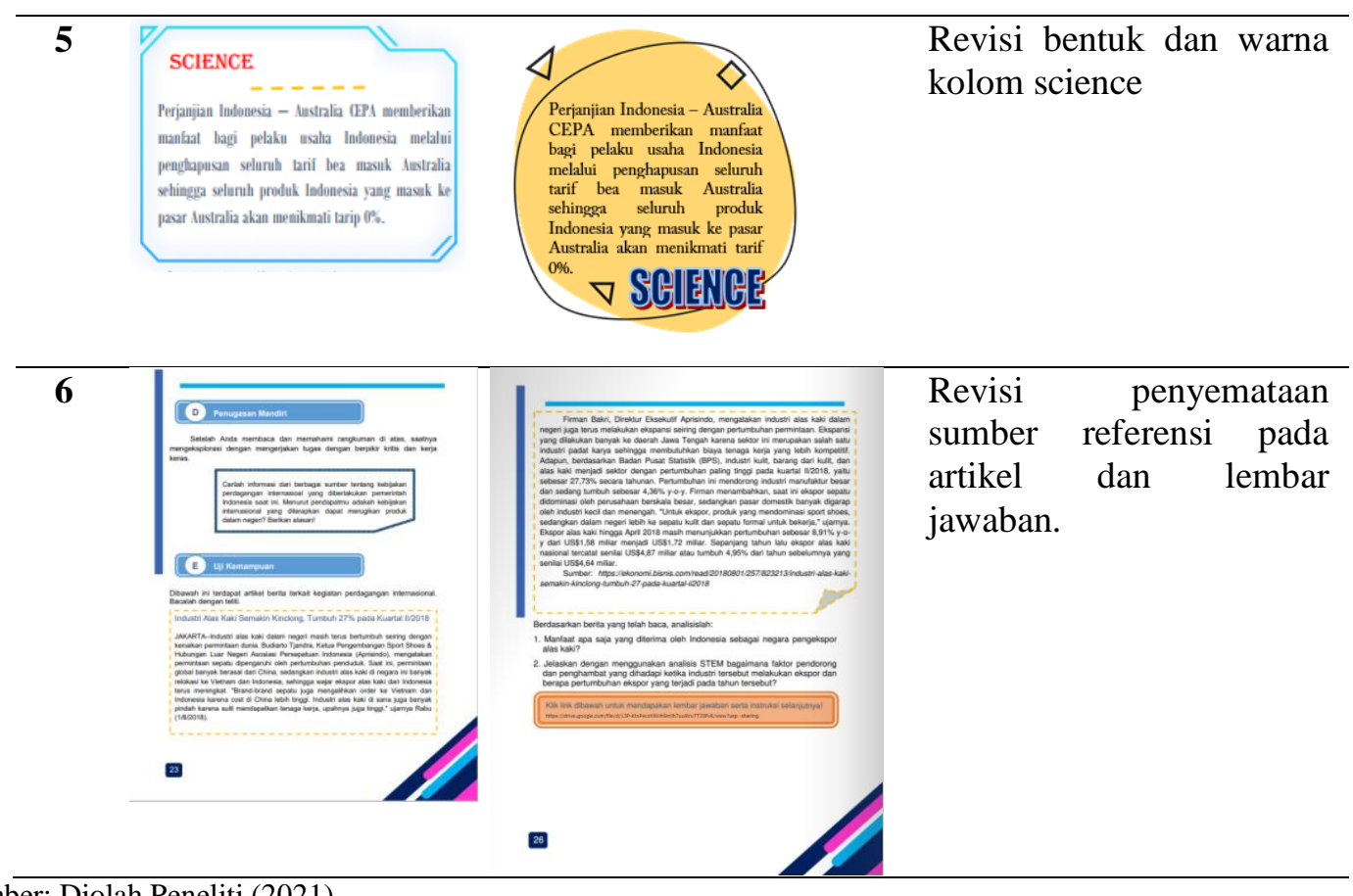

Sumber: Diolah Peneliti (2021)

E-Modul selesai ditelaah, maka selanjutnya untuk mengetahui kelayakan dari E-Modul Perdagangan Internasional dilakukan validasi oleh ahli media, evaluasi, dan materi yang dilakukan oleh salah satu dosen Jurusan Pendidikan Ekonomi Universitas Negeri Surabaya. Pada penelitian ini E-Modul dikatakan layak apabila presentasi hasil validasi sebesar $\geq 61 \%$. Maka hasil dari validasi akan diproses menggunakan metode deskriptif kuantitatif yang kemudian dikembangkan menjadi bentuk persentase. Hasil penilaian dari para ahli disajikan dalam tabel 6.

Tabel 6. Tabel Rata-Rata Hasil Penilaian atau Validasi

\begin{tabular}{clcc}
\hline No. & Validator & Skor & Keterangan \\
\hline 1. & Ahli Materi & $92,6 \%$ & Sangat Baik \\
\hline 3. & Ahli Media & $91,05 \%$ & Sangat Baik \\
\hline 4. & Ahli Evaluasi & $93,06 \%$ & Sangat Baik \\
\hline Rata-rata & $\mathbf{9 2 , 2 3 \%}$ & Sangat Baik \\
\hline Sumber: diolah Peneliti (2021) & &
\end{tabular}

Uji Coba dilaksanakan setelah E-Modul berbasis STEM dengan materi Perdagangan Internasional selesai divalidasi oleh para ahli. Subjek dari Uji coba ini merupakan peserta didik kelas XI IPS 1 SMA Negeri 14 Surabaya dengan jumlah 34 peserta didik. Percobaan dilaksanakan dengan metode menyebarkan link EModul melalui grup WhatsApp kelas XI IPS 1, kemudian peserta didik masuk ke meeting Google Meet untuk diberikan arahan agar uji coba E-Modul dapat kondusif. Selanjutnya selesai menggunakan E-Modul Perdagangan Internasional, peserta didik diberikan angket melalui grup WhatsApp untuk mengukur kepraktisan dari E-Modul yang telah dikembangkan. Data hasil tanggapan peserta didik kelas XI IPS 1 dimuat pada tabel 7 .

Tabel 7. Tabel Hasil Tanggapan Peserta didik

\begin{tabular}{lcc}
\hline \multicolumn{1}{c}{ Komponen } & X & Keterangan \\
\hline Materi & 4,12 & Sangat Baik \\
\hline Penyajian & 3,78 & Sangat Baik \\
\hline Bahasa & 4,16 & Sangat Baik \\
\hline Kegrafikan & 4,05 & Sangat Baik \\
\hline Rata-rata Hasil Respon Peserta Didik & 4,02 & Sangat Baik \\
\hline Sumber: diolah Peneliti (2021) & &
\end{tabular}


Penilaian kemandirian peserta didik dilakukan dengan menggunakan instrument penyebaran angket pada peserta didik. Tujuan dari penyebaran angket ini untuk data tingkat kemandirian peserta didik selama menggunakan E-Modul dalam pembelajaran. Angket disebarkan kepada 34 peserta didik di kelas XI IPS 1 sebelum dan sesudah pembelajaran menggunakan modul yang telah dikembangkan.

Tabel 8. Hasil Angket Kemandirian Belajar

\begin{tabular}{cccc}
\hline $\begin{array}{c}\text { Total Skor Angket } \\
\text { Kemandirian Belajar } \\
\begin{array}{c}\text { Sebelum Peggunaan } \\
\text { Media }\end{array}\end{array}$ & $\begin{array}{c}\text { Total Skor Angket } \\
\text { Kemandirian Belajar } \\
\text { Setelah Penggunaan } \\
\text { Media }\end{array}$ & Gain Score & Kategori \\
\hline 1489 & 1902 & 0,57 & Sedang \\
\hline Sumber : Diolah Peneliti (2021) & & &
\end{tabular}

Berdasarkan hasil dari angket yang disebarkan pada peserta didik sebelum (pretest) dan sesudah (posttest) penggunaan E-Modul Perdagangan Internasional, bahwa adanya peningkatan kemandirian dari perhitungan skor rata-rata sebesar 0,57 dengan kategori "Peningkatan Sedang". Untuk melihat adanya tidaknya pengaruh E-modul terhadap kemandirian belajar, peneliti melakukan uji normalitas dan uji t. Untuk hasil normalitas dapat dilihat pada gambar 8 dan hasil uji t dapat dilihat pada tabel 9 .

Hypothesis Test Summary

\begin{tabular}{|lccl|}
\hline \multicolumn{1}{|c}{ Null Hypothesis } & Test & Sig. & Decision \\
\hline $\begin{array}{l}\text { The distribution of Pretest is norma Dne-Sample } \\
\text { with mean } 43.79 \text { and standard } \\
\text { deviation } 2.31 .\end{array}$ & $\begin{array}{l}\text { Kolmogorov- } \\
\text { Smirnov Test }\end{array}$ & $.792 \begin{array}{l}\text { Retain the } \\
\text { null } \\
\text { hypothesis. }\end{array}$ \\
\hline $\begin{array}{l}\text { The distribution of Posttest is } \\
\text { normal with mean 55.94 and } \\
\text { standard deviation 2.59. }\end{array}$ & $\begin{array}{l}\text { One-Sample } \\
\text { Kolmogory- } \\
\text { Smirnov Test }\end{array}$ & $\begin{array}{l}\text { Retain the } \\
\text { null } \\
\text { hypothesis. }\end{array}$ \\
\hline
\end{tabular}

Asymptotic significances are displayed. The significance level is 05 .

Gambar 8. Hasil Uji Normalitas

Sumber: SPSS 20

Berdasarkan tabel output uji normalitas SPSS, ditemukan bahwa nilai sig. masing-masing sebesar 0,792 dan 0,806. Berdasarkan keputusan dalam uji normalitas Kolmogorovskmirnov, disimpulkan bahwa data berdistribusi normal sehingga memenuhi syarat normalitas.

Tabel 9. Tabel Hasil Uji Paired Samples T Test

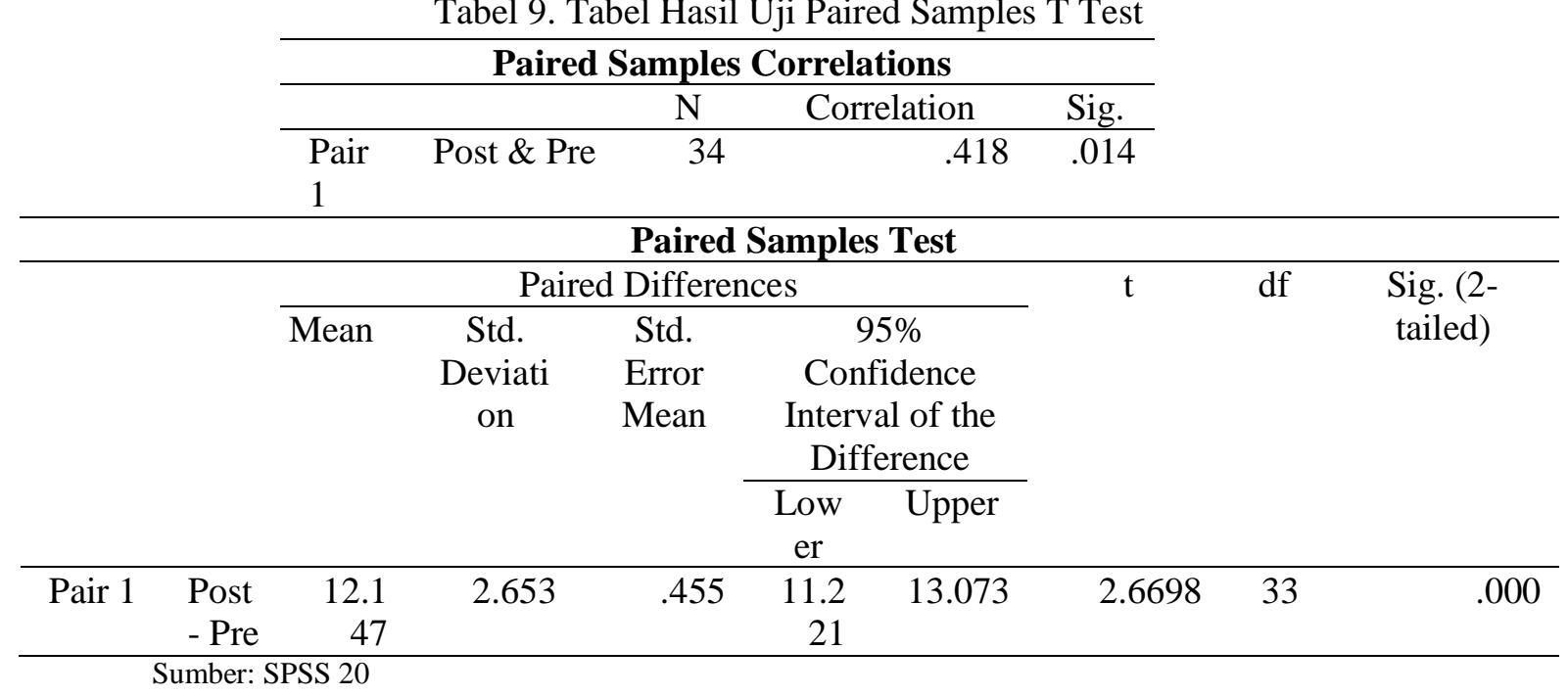

Dari hasil paired samples correlationas antara hubungan variabel Pretest dan variabel Posttest menunjukan nilai koefisien korelasi sebesar dengan nilai signifikansi (Sig.) sebesar 0,014 karena nilai Sig. lebih kecil dari pada nilai probabilitas 0,05, maka disimpulkan adanya pengaruh E-modul berbasis STEM terhadap kemandirian belajar. 
Selanjutnya pada pembahasan penelitian pengembangan ini memaparkan tentang pengembangan atau validitas e-modul berbasis STEM, respon peserta didik terhadap e-modul, efektivitas e-modul serta pengaruh E-modul terhadap kemandirian belajar peserta didik. Berdasarkan hasil penelitian pengembangan kesesuaian produk akhir dengan tujuan penelitian, hasil validasi ahli yang terdiri dari ahli materi, media dan evaluasi serta hasil tes dan penyebaran angket.

\section{Pengembangan E-Modul Berbasis Science, Technology, Engineering and Mathematic pada Materi Perdagangan Internasional}

E-Modul dapat digunakan ketika sudah mendapatkan digunakan ketika sudah mendapatkan kriteria layak. Kelayakan E-Modul berbasis Science, Technology, Engineering and Mathematic (STEM) diukur melalui hasil validasi para ahli mulai dari ahli materi, media, dan evaluasi. Jenis data hasil dari validasi para ahli berupa data deskriptif kuantitatif, yang mana data berupa angka yang dianalisis dalam bentuk kalimat.

Angket penilaian atau validasi ahli materi memiliki empat aspek yang meliputi aspek kelayakan isi, aspek kelayakan penyajian, aspek kelayakan bahasa menurut BSNP, aspek penilaian STEM. Hasil dari masing-masing sub aspek sebagai berikut: (1) Aspek kelayakan isi dengan indikator kesesuaian materi dengan $\mathrm{KD}$, mendorong keingintahuan, kemuntakhiran materi, dan keakuratan materi mendapat presentasi hasil sebesar 90,67\%; (2) Aspek kelayakan penyajian yang terdiri atas empat indikator yaitu pendukung penyajian, teknik penyajian, penyajian pembelajaran, dan koherensi serta keruntutan alur pikir memperoleh presentasi hasil sebesar 96,67\%; (3) Aspek kelayakan bahasa menurut BSNP dengan indikator sebagai berikut lugas, kesesuaian dengan perkembangan peserta didik, dialogis dan interaktif, kesesuaian dengan kaidah bahasa, dan komunikatif mendapatan skor sebesar 88\%; (4) Aspek penilaian STEM yang terdiri atas dua indikator yaitu hakiket STEM dan Komponen STEM. Dari data tersebut menunjukan bahwa rata-rata hasil penilaian atau validasi ahli materi memperoleh nilai presentase 92,6\%. Seluruh aspek dalam validasi materi memperoleh kriteria "sangat layak". Menurut (Riduwan, 2012) nengenai kriteria untuk menafsirkan presentase, jika persentase rata-rata media lebih besar dari $61 \%$ maka media dianggap dapat diterima. Hal ini dapat berarti bahwa E-Modul berbasis STEM pada Materi Perdagangan Internasional memenuhi kriteria karena memperoleh skor persentase lebih dari $61 \%$.

Angket validasi selanjutnya ialah penilaian atau validasi ahli media yang mana terdiri atas aspek kelayakan kegrfikan menurut BSNP. Pada aspek kelayakan kegrafikan memiliki tiga indiktor yaitu desain sampul modul, ukuran modul, dan desain isi modul dengan presentase hasil masing-masing indictor memperoleh skor 90\%; 94,25\%; 88\% dengan kategori "sangat layak". Perolehan rata-rata skor penilaian ahli media yaitu 91,05\% dengan kategori "sangat layak", menunjukakan bahwa E-Modul berbasis STEM pada Materi Perdagangan Internasional memenuhi kriteria kelayakan karena memperoleh skor persentase lebih dari $61 \%$.

Selanjutnya merupakan penilaian ahli evaluasi, dengan aspek materi memperoleh presentase sebesar $86,67 \%$, aspek konstruksi sebesar 97,5\%, dan aspek bahasa memperoleh sebesar 95\%. Seluruh aspek dalam angket evaluasi memperoleh kategori "sangat layak". Dengan perolehan rata-rata skor validasi ahli evaluasi lebih besar dari $61 \%$ yaitu sebesar 93,06\% maka dapat dikatakan E-Modul berbasis STEM pada Materi Perdagangan Internasional dapat memenuhi kriteria layak.

Secara keseluruhan rata-rata nilai validasi para ahli mulai dari penilaian materi, media, dan evaluasi sebesar 92,23\% menunjukan bahwa E-Modul berbasis Science, Technology, Engineering and Mathematic sangat layak dimanfaatkan sebagai alternative bahan ajar untuk pelajar. Penelitian lain oleh (Suryani et al., 2020) dengan judul Pengembangan Modul Digital berbasis STEM menggunakan Aplikasi 3D FlipBook pada Mata Kuliah Sistem Operasi memperoleh hasil validasi para ahli sebesar 92,44\% dan dinyatakan valid untuk digunakan sebagai sumber belajar oleh peserta didik. Relevansi keduanya sama-sama dinyatakan valid oleh para ahli, menunjukan bahwa pengembangan E-modul berbasis STEM dengan materi Perdagangan Internasional layak digunakan sumber belajar. 
2233 Pengembangan E-Modul Berbasis STEM untuk Meningkatan Kemandirian Belajar dalam Pembelajaran Jarak Jauh pada Mata Pelajaran Ekonomi - Pingki Jelita Mulyasari, Ni'matush Sholikhah

DOI: https://doi.org/10.31004/edukatif.v3i4.1158

\section{Respon Peserta Didik Terhadap E-Modul Berbasis Science, Technology, Engineering and Mathematic pada Materi Perdagangan Internasional}

Angket respon peserta didik terdiri dari 11 item pertanyaan yang mencangkup empat aspek yaitu kegrafikan, penyajian, materi, bahasa, dan. Angket berisikan pernyataan dan jawaban dengan lima alternative jawaban. Menurut (Azwar, 2007) berkenaan dengan konversi jumlah poin yang sebenarnya menjadi skala lima poin, rata-rata dianggap layak jika jumlah rata-rata poin lebih besar dari 3,34. Hasil respon peserta didik memperoleh rata-rata sebesar 4,02 dengan katergori sangat layak. Untuk rinciannya sebagai berikut: aspek materi sebesar 4,12; aspek penyajian sebesar 3,78; aspek bahasa sebesar 4,16; dan aspek kegrafikan sebesar 4,05. Penelitian lain oleh (Tripripa et al., 2020) dengan judul Pengembangan Modul Larutan Penyangga Berbasis Pendekatan Terpadu STEM menyebutkan bahwa respon peserta didik terhadap modul tersebut sangat baik dengan rata-rata nilai sebesar 4,3.

Dari hasil respon peseta didik dapat diartikan bahwa E-Modul Berbasis Science, Technology, Engineering and Mathematic dengan Materi Perdagangan Internasional memiliki manfaat atau praktis bagi peseta didik. Menurut respon peserta didik E-modul ini dapat dimanfaatkan sebagai salah satu sumber belajar materi perdagangan internasional pada masa pembelajaran jarak jauh.

\section{Efektivitas E-Modul Berbasis Science, Technology, Engineering and Mathematic pada Materi Perdagangan Internasional}

Untuk mengetahui efektivitas E-Modul Berbasis STEM pada materi perdagangan internasional pada tingkat kemandirian peserta didik diukur dengan memberikan angket pretest dan posttest. Angket berisi pretest diberikan pada peserta didik sebelum menggunakan E-Modul Berbasis Science, Technology, Engineering and Mathematic dengan memperoleh hasil sebesar 1489. Sedangkan posttest diberikan setelah penggunaan E-Modul dengan memperoleh hasil sebesar 1902. Sehingga memperoleh nilai gain sebesar 0,57, dari hasil gain score memperlihatkan bahwa peningkatan kemandirian peserta didik tergolong dalam kategori sedang. Berdasarkan nilai gain maka tingkat kemandirian belajar mengalami peningkatan dengan kategori sedang dan penggunaan E-Modul berbasis STEM pada materi Perdagangan Internasional efektif dan layak dimanfaatkan untuk salah satu sumber belajar. Hasil penelitian ini sejalan dengan penelitian dari (Nurhayati et al., 2015), hasil penelitiannya menyimpulkan efektivitas penggunaan modul fisika berbasis inkuiri terhadap kemandirian belajar sebesar 0,31 tergolong sedang.

Penggunaan e-modul berbasis STEM ini memberikan kesempatan pada pelajar untuk belajar sesuai dengan kecepatan dan cara masing-masing. Dengan adanya e-modul ini diharapkan peserta didik dapat berlatih mandiri, belajar mengembangkan logika berfikir dan penalarannya. Selain itu dengan menggunakan E-modul ini peserta didik lebih interaktif dimana e-modul ini dilengkapi dengan fasilitas multimedia seperti gambar atau video, kemudian peserta didik dapat melakukan evaluasi diri terhadap suatu kompetensi secara mandiri. Seperti yang dapat dilihat dari uraian di atas kegunaan E-modul berbasis STEM dapat digunakan untuk meningkatkan kemandirian belajar pengguna, sehingga dapat belajar secara mandiri sesuai kemampuannya sendiri.

\section{Pengaruh E-Modul Berbasis STEM Terhadap Kemandirian Belajar Peserta Didik Pada Pembelajaran Jarak Jauh Mata Pelajaran Ekonomi Di SMA N 14 Surabaya}

Untuk mengetahui ada tidaknya pengaruh E-Modul Berbasis Science, Technology, Engineering and Mathematic terhadap kemandirian belajar peserta didik diukur dengan memberikan angket pretest dan posttest. Angket yang diberikan berisikan tiga aspek yaitu personal attribute, process, dan learing context. Kemudian data diolah menggunakan bantuan program SPSS, berdasarkan tabel paired samples test diketahui bahwa nilai Sig. (2-tailed) adalah 0,000 <0,05. Sehingga dapat disimpulkan bahwa ada perbedaan hasil ratarata kemandirian belajar dari sebelum penggunaan media dan setelah penggunaan media, yang artinya ada pengaruh penggunaan E-Modul Berbasis Science, Technology, Engineering and Mathematic pada Materi 
Perdagangan Internasional terhadap kemandirian peserta didik secara signifikan. Nilai perbedaan rata-rata berpasangan adalah 12.147, nilai ini menunjukkan perbedaan antara rata-rata hasil pre-test dan post-test.

Penelitian yang dilakukan (Guntur et al., 2017) dengan judul Pengaruh Penggunaan Bahan Ajar Matematika Bersuplemen Komik Terhadap Kemandirian Belajar Peserta Didik Hal ini menunjukkan bahwa terdapat pengaruh terhadap kemandirian belajar peserta didik antara yang banyak menggunakan komik, yang jarang menggunakan komik dan yang tidak menggunakan komik sebagai sumber belajar. Relevansi terhadap penelitian tersebut melihat pengaruh komik sebagai bahan ajar terhadap kemandirian peserta didik. Sama dengan e-modul berbasis STEM ini, bahan ajar ini dapat mempengaruhi tingkat kemandirian peserta didik. Penelitian serupa juga dikemukakan oleh (Linda \& Putra, 2021) memperoleh hasil bahwa implementasi emodul interaktif dapat meningkatkan kemandirian belajar peserta didik pada kategori sedang manjadi tinggi dan peningkatkan hasil belajar dengan kategori sedang.

Hasil penelitian (Irwandani et al., 2017) menyatakan bahwa modul digital dirancang untuk memungkinkan peserta didik belajar secara mandiri untuk meningkatkan hasil belajar. E-Modul berbasis STEM dirancang dan disediakan fitur-fitur yang menunjang kegiatan belajar peserta didik secara mandiri dalam pembalajaran jarak jauh. E-Modul yang dikembangkan terdapat media gambar dan video yang berfungsi dengan baik, yang membantu peserta didik dalam mengamati objek sehingga meningkatkan pemahaman. Kegiatan penugasan mandiri dan uji kemampuan dapat menggugah semangat karena peserta didik dapat berkreasi dalam menyampaikan ide-idenya secara leluasa. Selain itu juga dapat mendorong rasa tanggungjawab dan disiplin dengan menjawabnya pada link yang tersedia secara mandiri. Hal ini sejalan dengan karakteristik E-modul self instructional, ketika peserta didik menggunakan E-modul dengan petunjuk yang tersedia dan tidak bergantung pada orang lain. Selain itu di akhir kegiatan pembelajaran terdapat lembar evaluasi diri, dimana dapat digunakan peserta didik untuk mengukur kemampuannya menguasai materi sebelum melanjutkan ke kegiatan pembelajaran selanjutnya. Kemudian peserta didik dapat menyelesaikan tujuan pembelajaran secara bertahap.

\section{KESIMPULAN}

Penelitian ini bermaksud untuk mengembangkan E-modul berbasis pada materi Perdagangan Internasional untuk meningkatkan kemandirian belajar peserta didik XI IPS 1 SMA N 14 Surabaya. Berdasarkan hasil penelitian dapat disimpulkan sebegai berikut: Pengembangan E-Modul dapat digunakan ketika modul sudah dikatakan layak. Kelayakan E-Modul berbasis STEM pada materi Perdagangan Internasional yang dikembangkan berdasarkan validasi para ahli memenuhi kriteria kelulusan validasi ahli materi, media, dan evaluasi. Respon peserta didik terhadap kepraktisan E-modul diukur menggunakan angket respon peserta didik terhadap E-Modul berbasis STEM pada materi Perdagangan Internasional memperoleh kategori sangat layak. Untuk efektivitas E-Modul berbasis STEM pada materi Perdagangan Internasional dalam meningkatkan kemandirian peserta didik selama pembelajaran jarak jauh yang diukur menggunakan uji gain score yang menunjukan adanya peningkatkan kemandirian dengan kategori sedang. Berdasarkan uji coba pada kelas XI IPS 1 SMA N 14 Surabaya diperoleh, ada pengaruh penggunaan E-Modul Berbasis Science, Technology, Engineering and Mathematic dengan materi Perdagangan Internasional terhadap kemandirian peserta didik secara signifikan.

\section{DAFTAR PUSTAKA}

Amiti, F. (2020). Synchronous And Asynchronous E-Learning. European Journal Of Open Education And ELearning Studies, 5(2), 141-153. Https://Doi.Org/10.46827/Ejoe.V5i2.3313

Ariana, D., Situmorang, R. P., \& Krave, A. S. (2020). Pengembangan Modul Berbasis Discovery Learning Pada Materi Jaringan Tumbuhan Untuk Meningkatkan Kemampuan Literasi Sains Siswa Kelas Xi Ipa Sma. Jurnal Pendidikan Matematika Dan Ipa, 11(1), 34. Https://Doi.Org/10.26418/Jpmipa.V11i1.31381 
2235 Pengembangan E-Modul Berbasis STEM untuk Meningkatan Kemandirian Belajar dalam Pembelajaran Jarak Jauh pada Mata Pelajaran Ekonomi - Pingki Jelita Mulyasari, Ni'matush Sholikhah DOI: https://doi.org/10.31004/edukatif.v3i4.1158

Arikunto, S. (2012). Prosedur Penelitian Suatu Pendekatan Praktik. Rineka Cipta.

Astuti, D., \& Prabowo, A. (2020). Pengembangan Bahan Ajar Educational Statistics Untuk Meningkatkan Kemandirian Dan Hasil Belajar Mahasiswa. 9(4), 1172-1183. Https://Doi.Org/Https://Doi.Org/10.24127/Ajpm.V9i4.3167

Azwar, S. (2007). Tes Prestasi Fungsi Dan Pengembangan Pengukuran Prestasi Belajar. Pustaka Belajar.

Damayanti, E., Nurazizah, E., \& Rahayu, M. D. (2010). Modul Statistika Induktif Uji Paired Sample T Test, Uji Independent Sample T Test Dan Uji Wilcoxon. (Issue June).

Fausih, M., \& Danang, T. (2015). Pengembangan Media E-Modul Mata Pelajaran Produktif Pokok Bahasan "Instalasi Jaringan Lan (Local Area Network)" Untuk Siswa Kelas Xi Jurusan Teknik Komputer Jaringan Di Smk Nengeri 1 Labang Bangkalan Madura. Jurnal Unesa, 01(01), 1-9. Https://Jurnalmahasiswa.Unesa.Ac.Id/Index.Php/Jmtp/Article/View/10375

Ghozali, I. (2016). Aplikasi Analisis Multivariete Dengan Program Ibm Spss 23 (Edisi 8). Badan Penerbit Universitas Diponegoro.

Guntur, M., Muchyidin, A., \& Winarso, W. (2017). Pengaruh Penggunaan Bahan Ajar Matematika Bersuplemen Tadris Matematika. Eduma Mathematics Education Learning And Teaching, July. Https://Doi.Org/10.24235/Eduma.V6i1.1667

Hake, R. (1999). Analyzing Change/Gain Scores. Dept. Of Physics, Indiana University. Https://Www1.Physics.Indiana.Edu/ Sdi/Analyzingchange-Gain.Pdf

Irwandani, Latifah, Asyhari, Muzannur, \& Widayanti. (2017). Modul Digital Interaktif Berbasis Articulate Studio'13: Pengembangan Pada Materi Gerak Melingkar Kelas X. Jurnal Ilmiah Pendidikan Fisika AlBiruni, 6(2). Https://Doi.Org/Https://Doi.Org/10.24042/Jipfalbiruni.V6i2.1862

Linda, R., \& Putra, T. P. (2021). Peningkatan Kemandirian Dan Hasil Belajar Peserta Didik Melalui Implementasi E-Modul Interaktif Ipa Terpadu Tipe Connected Pada Materi Energi Smp / Mts Pendahuluan. 9(2), 191-200. Https://Doi.Org/10.24815/Jpsi.V9i2.19012

Mardapi, D. (2008). Teknik Penyusunan Instrumen Tes Dan Non Tes. Mitra Cendikia Press.

Nurhayati, Saputri, D. F., \& Sari, I. N. (2015). Efektivitas Penggunaan Modul Fisika Berbasis Inkuiri Terhadap Hasil Belajar Dan Kemandirian Belajar Mahasiswa. Jurnal Pendidikan Informatika Dan Sains, 4(2), 250-253. Https://Doi.Org/Http://Dx.Doi.Org/10.31571/Saintek.V4i2.74

Pancawati, D. (2020). Suka Duka Belajar Di Rumah: Keputusan Pemerintah Menerapkan Belajar Dari Rumah Di Wilayah Terdampak Virus Covid-19 Bukanlah Hal Mudah Diterapkan Di Indonesia. Bebas Kompas. Https://Bebas.Kompas.Id/Baca/Riset/2020/03/26/Suka-Duka-Belajar-Di-Rumah/

Prawiyogi, A. G., Purwanugraha, A., Fakhry, G., \& Firmansyah, M. (2020). Efektifitas Pembelajaran Jarak Jauh Terhadap Pembelajaran Siswa Di Sdit Cendekia Purwakarta. Jurnal Pendidikan Dasar, 11(01), 94 101. Https://Doi.Org/Doi.Org/10.21009/Jpd.011.10

Puspitasari, R. D., Herlina, K., \& Suyatna, A. (2020). A Need Analysis Of Stem-Integrated Flipped Classroom E-Module To Improve Critical Thinking Skills. Indonesian Journal Of Science And Mathematics Education, 3(2), 178-184. Https://Doi.Org/10.24042/Ijsme.V3i2.6121

Sugiyono. (2012). Metode Penelitian Kuantitatif, Kualitatif, Dan R\&D. Alfabeta.

Sugiyono. (2015). Metode Penelitian Pendidikan Kuantitatif, Kualitatif, Dan R\&D. Cv Alvabeta.

Suryani, K., Utami, I. S., Khairudin, K., Ariska, A., \& ... (2020). Pengembangan Modul Digital Berbasis Stem Menggunakan Aplikasi 3d Flipbook Pada Mata Kuliah Sistem Operasi. Jurnal Mimbar Ilmu, 25(3), 358367. Https://Ejournal.Undiksha.Ac.Id/Index.Php/Mi/Article/View/28702

Suwasono. (2013). Pengembangan E-Modul Online Elektronika Analog Pada Pendidikan Jarak Jauh. Teknologi Dan Kejuruan, 36(1), 51-62. Https://Doi.Org/Http://Dx.Doi.Org/10.17977/Tk.V36i1.4070 
2236 Pengembangan E-Modul Berbasis STEM untuk Meningkatan Kemandirian Belajar dalam Pembelajaran Jarak Jauh pada Mata Pelajaran Ekonomi - Pingki Jelita Mulyasari, Ni'matush Sholikhah DOI: https://doi.org/10.31004/edukatif.v3i4.1158

Torlakson, T. (2014). Innovate: A Blueprint For Science. Technology, Engineering, And Mathematics In California Public Education. Californians Dedicated To Education Foundation.

Tripripa, A., Amir, H., \& Rohiat, S. (2020). Pengembangan Modul Larutan Penyangga Berbasis Pendekatan Terpadu Stem (Science, Technology, Engineering And Mathematics). Jurnal Pendidikan Dan Ilmu Kimia, 4(1), 16-24. 